Proc. Indian Acad. Sci. (Earth Planet. Sci.), Vol. 93, No. 1, March 1984, pp. 71-77.

(C) Printed in India.

\title{
A note on the petrochemistry of the Konthainhundi pluton, District Mysore, Karnataka
}

\author{
S G KARKARE, R K OJHA and R C SRIVASTAVA \\ Department of Geology, Banaras Hindu University, Varanasi 221005 , India \\ MS received 14 December 1982; revised 17 August 1983
}

\begin{abstract}
The Konthainhundi suite represents a syn to post orogenic calc-alkalic to alkalicalcic series. The rocks were a result of the collapse of a shallow level magma chamber aided by caldera subsidence.
\end{abstract}

Keywords. Petrochemistry; Konkanhundi pluton.

\section{Introduction}

Konthainhundi (Konkanhundi) pluton $30 \mathrm{~km}$ SE of Mysore on the NanjangudThagdur road is the only example of a layered mafic complex from Peninsular India. Jayram $(1907,1913)$ considered it to be a part of the gneissic complex. Ramkrishnan and Mallikarjun of the Geological Survey of India classified it as a layered basic complex in 1976. The present work covers a part of the geological map presented by the previous workers and is in agreement with their findings.

\section{Geological setting}

The roughly oval layered mafic pluton is $2500 \mathrm{~m}$ thick and covers $c a 50 \mathrm{~km}^{2}$. The longer diameter is almost $\mathbf{N}-\mathrm{S}$. It is emplaced with sharp contacts into the basement gneissic complex-hornblende schist and gneisses together with enclaves of amphibolite. The country rock strikes NNE with steep easterly dips of $75-80^{\circ}$. The repetitive sequence gabbro-norite-anorthosite forms the major part of the pluton and presents lanceolate tapering outcrops with arcuate patterns and evidence of weak folding. The layered rocks are intersected by dykes of dolerite, amphibolite and granite-pegmatite (figure 1).

The following order of succession has been worked out: pegmatite, microgabbro/dolerite anorthosite, norite and gabbro. In view of its uniform nature and local gradation to gabbro, norite bands cannot be given different status and it is more likely that they represent cone sheets.

\subsection{Gabbro}

Gabbros $(M>40)$ form the dominant type of the repetitive sequence Gabbro-noriteanorthosite, occurring as sheets in nalas. They are less fractured and jointed than norites which are relatively much weathered. Gabbros do not cut across norite 


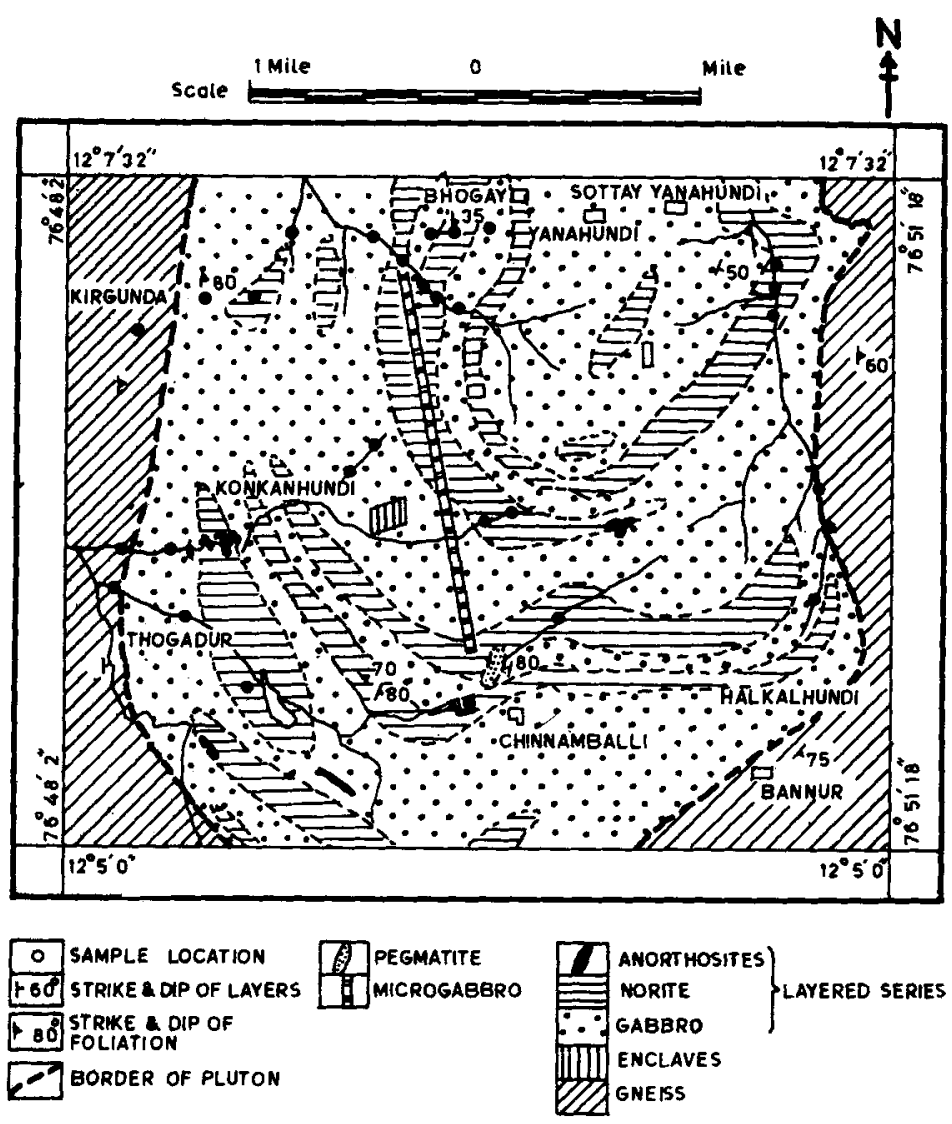

Figure 1. Geological map of Konkanhundi pluton, District Mysore, Karnataka.

anywhere. They are cut across by dykes of pegmatite, dolerites and by epidote veins.

Gabbros show their usual hypautamorphic granular rocks of dark green colour consisting of diopside calcic plagioclase $\left(\mathrm{An}_{58}\right) 2 \mathrm{Vx}=78^{\circ}$, extinction angle 25-28 on albite-lamellae as dominant minerals together with hornblende, apatite, magnetite and ilmenite form the accessories. The plagioclase is highly saussuritised and hornblende has been observed to grow from intercumulus fluid between plagioclase crystals. Hornblende alters to uralite and flaky biotite. In the mafic variety hornblende dominates, reaching up to $56 \%$ by volume.

\subsection{Norite}

Norite forms independant outcrops as at Kallkunda, besides the repetitive parallel sheets with gabbro. They show gradation to gabbro near Chinnamaballi. Norites are composed of hypersthene (upto $25 \%$ by volume) and labradorite (upto $60 \%$ ) some diopside, hornblende, cummingtonite, ilmenite and leucoxene form accessories. Hypersthene reveals schiller structure with exsolved lamellae of clinopyroxene. They also show rim coronas of cummingtonite. 


\subsection{Metagabbro or metanorite}

These are rather common metamorphosed varieties of gabbro and norite with $M>65$ and similar texture.

\subsection{Hornblendite}

Mainly composed of hornblende $(M \approx 90)$.

\subsection{Anorthosites}

They form an integral part of the repetitive sequence with gabbro and norite. They are of two varieties-a dark grey coloured associated with norite and a milky white resembling marble associated with gabbro. They reveal the typical cumulus texture with occasional streaks of dark coloured minerals. The plagioclase (upto $98 \%$ by volume) is $\mathrm{An}_{40}$ in white variety and $\mathrm{An}_{50}$ in the dark variety. They reveal glide twins, curved lamellae, periferal granulation and saussuritisation. Pyroxene and hornblende occur as irregular intercumulus phases and magnetite, ilmenite and apatite are common accessories.

\subsection{Microgabbro/dolerites}

Dykes of these rocks cut across rocks of the repetitive sequence. They have been metamorphosed to a low amphibolite facies. Dykes lacking ophitic texture are designated as micro-gabbros e.g. NE of Konkanhundi where the trend is NNW-SSE. They are made up of diopside, augite, plagioclase and intercumulus clinopyroxene. Apatite, magnetite, ilmenite and sphene are the accessories.

\subsection{Pegmatite}

Pegmatite dykes trending NNW-SSE cut across the basic plutonic rocks near Chinnamballi and Konkanhundi. They are coarse grained (upto $3 \mathrm{~cm}$ ) granite pegmatites consisting of quartz, orthoclase and books of muscovite and biotite. Potash feldspar is perthitic as well as micrographic with angular quartz.

\subsection{Amphibolite}

The layered sequence, particularly hornblende gabbro has been subjected to metamorphism of amphibolite facies and we have partial transformation of the rock into vaguely schistose amphibolitic type. The inner portions still retain the igneous character. They are made up of plagioclase (oligoclase to andesine) and greenish brown hornblende, the latter altering to biotite. Apatite, magnetite and ilmenite are common accessories.

Since the rock sequence gabbro-norite-anorthosite constitutes the layered series, detailed study of layering and related texture/structure was carried out. The results are given below. 
Cumulates of norites, diopsidic gabbro/norite, leuconorite and noritic anorthosites form part of the layered sequence with larger norites which are uniform and massive. Microlayers are made up of gabbro and norite. In these microlayers it is possible to make out fine scale 4 to $10 \mathrm{~cm}$ rhythmic layering. The heavy mafic-constituents of hornblende and hypersthene constitute the cumulus at the base-their proportion decreasing upwards into noritic anorthosite. The sequence matagabbro-normal gabbro-leucogabbro-anorthosite is repetitive. The layering may be aptly called "gravity stratification" (Buddington 1936). Cyclic layering is absent. However, trough banding is observed. The paragenetic sequence derived from various thin sections and polished samples clearly suggests that hypersthene (and in later stage clinopyroxene-diopsidic augite) and hornblende were the earlier heavy mineral phases that settled down. The iron ore minerals viz magnetite and ilmenite followed almost immediately afterwards and could be considered as synchronous with subsequent hornblende and diopsidic augite and hypersthene. The intercumulus liquid between the cumulates of hornblende, diopsidic augite and hypersthene, locally produced apatite. The crystallization of hornblende which follows that of pyroxene with which it shows a reaction relation was a prolonged one and extended into the later stages when plagioclase crescumulates were produced. In intermediate stages we have hypersthene plagioclase and hornblende plagioclase cumulates. In the anorthosite crescumulates hornblende continues to develop from intercumulus fluid. Thus the observed pattern of layering would develop from a gravity controlled, long range, slow crystallization differentiation [Wager et al (1960), Wager and Brown (1968)].

\section{Petrochemistry of the layered series}

Table 1 gives the analyses of the representative rock types together with their norms. Figure 2 is a silica variation diagram and figure 3 the FMA plot derived from these data. From the data presented here, the following conclusions may be drawn:

(i) There is an increase in $\mathrm{Na}_{2} \mathrm{O}, \mathrm{K}_{2} \mathrm{O}, \mathrm{Al}_{2} \mathrm{O}_{3}, \mathrm{SiO}_{2}$ and $\mathrm{Fe}_{2} \mathrm{O}_{3}$ and a decrease in $\mathrm{FeO}$, $\mathrm{MgO}$ and $\mathrm{TiO}_{2}$ with increasing degree of differentiation in the series gabbroanorthosite. $\mathrm{CaO}$ is nearly constant or shows a slight decrease.

(ii) Amphibolite plots suggest that this rock represents an early phase of gabbro which is slightly metamorphosed. The complete series is thus:

Amphibolite-microgabbro-norite-gabbroic anorthosite-anorthosite.

(iii) The alkali lime index of the series is 55 i.e. alkali-calcic (Peacock 1931).

(iv) Its ferrofemic index is $\mathbf{5 8}$ and there is no marked iron enrichment. It is a typical calcalkaline series with a trend parallel to Daly's average.

(v) The rocks were subjected to a mild regional metamorphism with attendant metasomatic phenomena such as uralitisation and saussuritisation.

(vi) The gabbroic rocks exhibit rhythmic layering on macro and micro scale and nonlayered norites form prominent bands within the layered series.

(vii) Crystal fractionation differentiation mostly by gravity settling and aided by convective currents was the largest single factor contributing to the diversification in the layered series. Large scale assimilation is precluded and fluctuations in $\mathrm{PO}_{2}$ have 


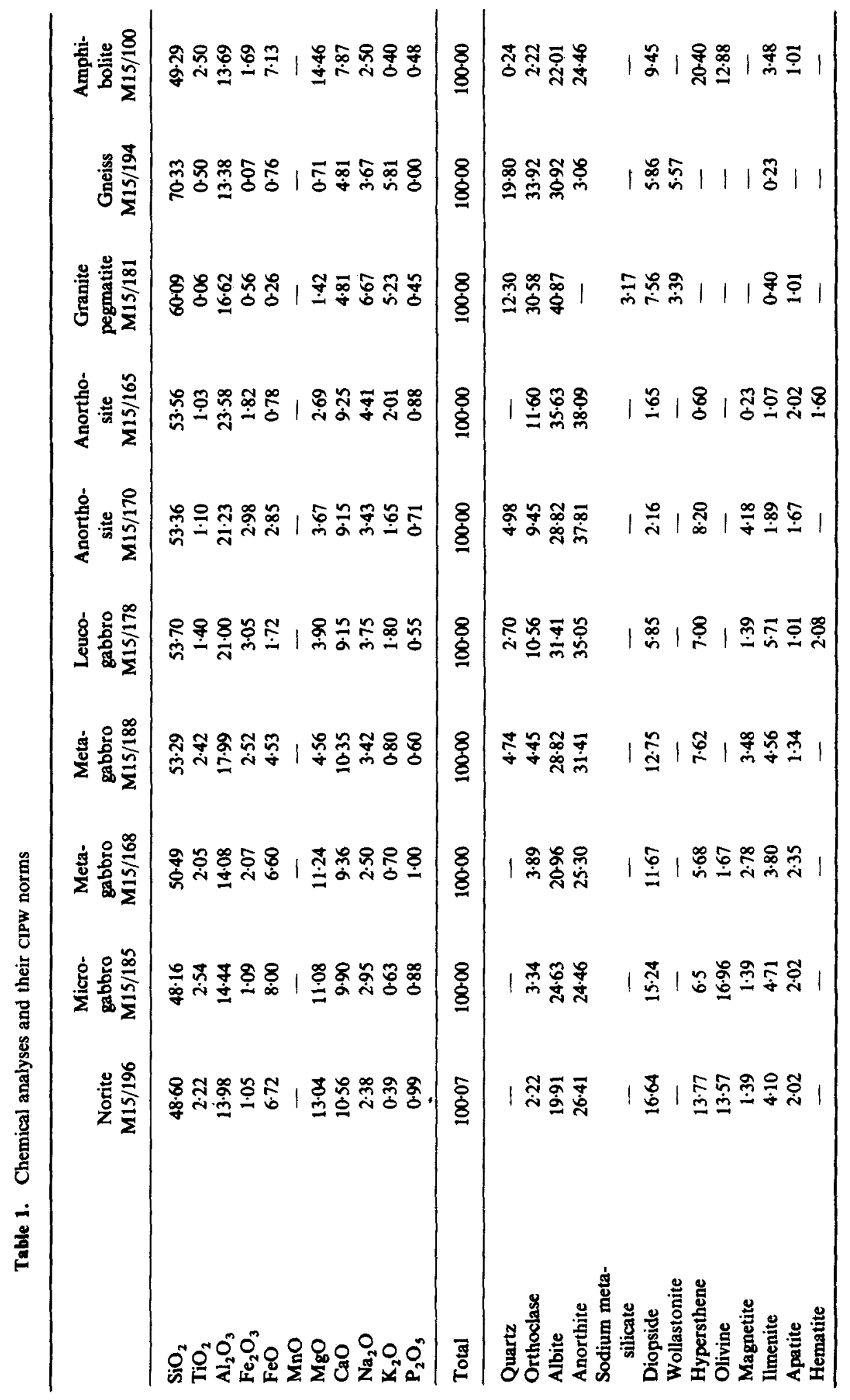




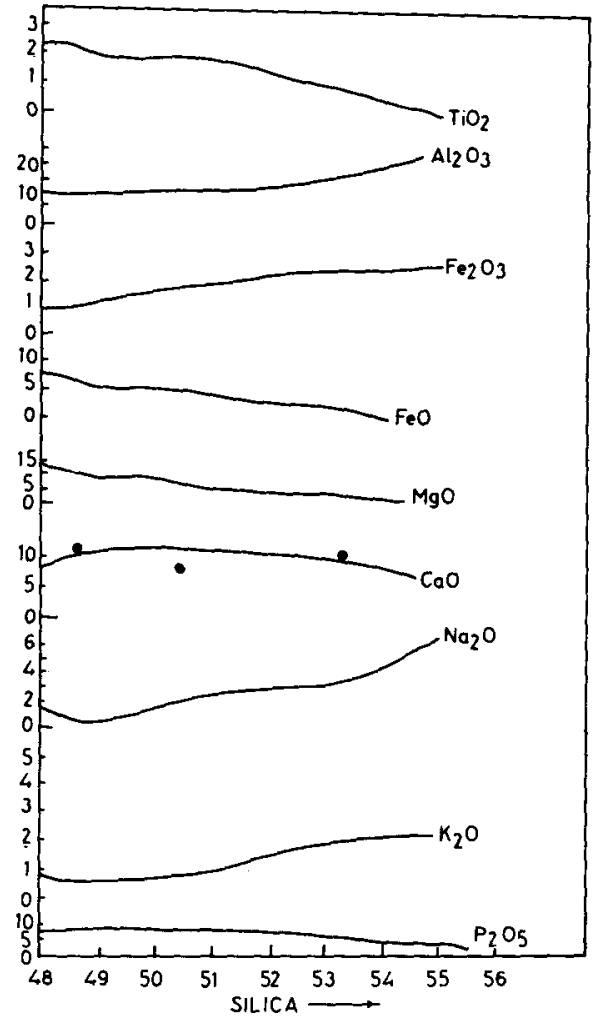

Figure 2. Diagram showing variation of oxides $v$ s silica (on separate scale).

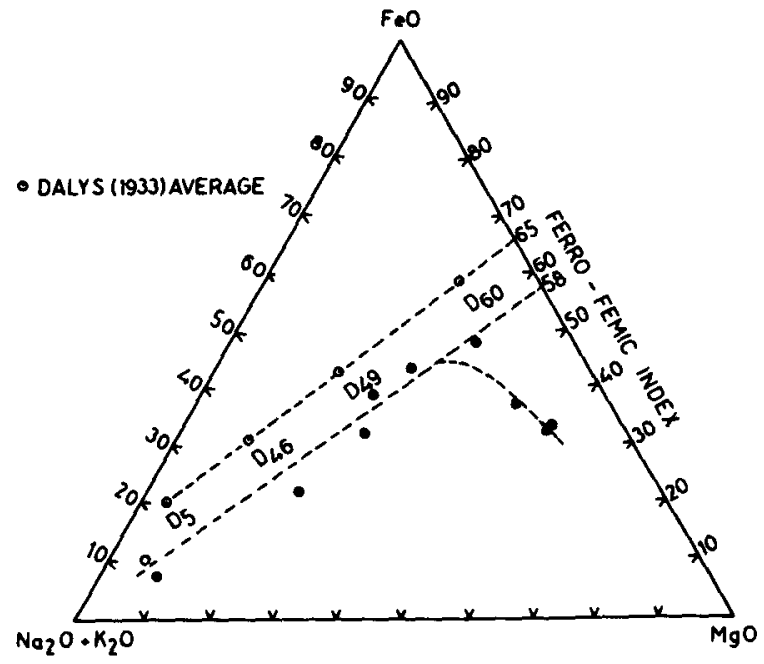

Figure 3. FMA diagram showing ferro femic index. 
resulted in formation of iron-rich gabbro and stringers of iron minerals, mostly magnetite.

The structure of this central type intrusion resembles cone sheets though the major part could as well have developed by caldera subsidence of the pluton.

Summarizing it may be said that the Konkanhundi suite represents a syn to postorogenic calc-alkalic to alkali-calcic series. The rocks were a result of the collapse of a shallow level magma chamber aided by caldera subsidence. A slight regional metamorphism has changed the gabbroic rocks into amphibolite types which nevertheless retain relict primary minerals and texture.

\section{Acknowledgements}

The authors are thankful to the Head of the Department of Geology for all facilities.

\section{References}

Bhattacharji S $1967 \mathrm{~J}$. Geol. 75101

Buddington A F 1936 Gravity stratification as a criterion in the interpretation of structure of certain intrusives of the northwestern adirandacks; 16th Int. Geol. Congr. Rep. Washington, 1933, p. 347

Carmichael I S E, Turner F J and Verhoogan J 1974 Igneous Petrol. (New York: McGraw Hill)

Jayaram S 1907 Rec. Mysore Geology Dept. Vol. 8, Part 2, p. 73

Jayaram S 1913 Rec. Mysore Geology Dept. Vol. 13, Part 2, p. 45

Johansen A 1937 A descriptive petrology of igneous rocks (Chicago: University Press) Vols 1 and 2, p. 360 Peacock M A 1931 J. Geol. 3954

Ramakrishnan M and Mallikarjuna C 1976 J. Geol. Soc. India 17207

Wager L R and Brown G M 1968 Layered igneous rocks (London: Oliver and Boyd) p. 588

Wager L R, Brown G M and Wadsworth W J 1960 J. Petrol. 173 